\title{
THE CLASH BETWEEN THE EMPLOYEE'S RIGHT TO PRIVACY AND FREEDOM OF EXPRESSION AND SOCIAL MEDIA MISCONDUCT: WHAT JUSTIFIES EMPLOYEE'S DISMISSAL TO BE A FAIR DISMISSAL?*
}

\author{
Simphiwe $\mathrm{P}$ Phungula \\ LLB LLM \\ Lecturer, Business Law, University of KwaZulu- \\ Natal \\ Advocate of the High Court of South Africa
}

\section{SUMMARY}

The $21^{\text {st }}$ century has an increase in the use of the internet as a means of trading. The use of the internet has also influenced the use of social media as a means of communication. This communication extends to the employer-employee relationship in the workplace. However - in South Africa - due to the rapid use of social media both in and out of the workplace, it has become blurry of what constitutes social media misconduct for which an employee may be disciplined. This is exacerbated by the lack of specific legislation dealing with employees and social media misconduct in South Africa. This article deals with the blessings and the curse of using social media as a means of communication in the workplace. It reveals the difficulties faced by both employers and employees when determining to what extent the behaviour of an employee can constitute adequate grounds for dismissal in relation to that employee's social media misconduct. Recommendations are made on the way forward.

For the past few years, South Africa has seen rapid growth in the use of social media as a means of communication. However, the use of social media by employees still needs to be developed. The lack of specific legislation regulating the conduct of employees on social media is an issue

Based on a paper presented at the Nelson Mandela University Labour Law Conference on "Labour Dispute Resolution, Substantive Labour Law and Social Justice Developments in South Africa, Mauritius and Beyond" from 19-21 July 2019 in Mauritius. 
affecting the relationship between employer and employee. Although social media can be recognised as an under-developed area of law in South Africa, its impact on labour law calls for critical consideration. It appears that the use of the internet and social media has brought both a blessing and a curse to the working place. On the one hand the internet and social media are a blessing for the employer's business in terms of advertising. Other than being a social platform, social media is, in fact, an important tool for business trade. ${ }^{1}$ On the other hand, the internet and social media are a curse on both the employer and the employee - particularly where an employer must decide whether or not the comments made by the employee on social media are a dismissible offence. This blessing and curse are inevitable in the modern world, and, as it stands, it is going to continue to be like this until there are specific social media guidelines put in place to govern the conduct of all employees on social media.

What has become a topical debate is the use of social media by an employee - particularly if an employee has posted comments on social media after working hours. Many cases that have been before the courts, the CCMA, and bargaining council, prove that the use of social media after working hours may have a negative impact on employees. The question is to what extent the behaviour of an employee can constitute adequate grounds for dismissal in relation to that of employee's social media misconduct. Without clear legislation or guidelines, the courts have - although not specifically $^{2}$ - provided some guidelines on what may be deemed to be an employee's unacceptable behaviour on social media. Since there is no specific legislation dealing with social media misconduct, it remains unclear which conduct may amount to dismissible misconduct, and which may not. Each case is decided depending on the facts put before the court. The dilemma lies in the fact that what can be viewed as social media misconduct by an employer may not necessarily be considered to be such by an employee at the time of posting a comment. The risk comes in when an employee makes comments in a personal capacity, and those comments are deemed to be damaging for the reputation of the employer - and the employee is then dismissed for social media misconduct. This is a complex issue, as it impacts on both the employee's right to freedom of expression and privacy, and also the employer's need to protect its reputation.

The purpose of this article is to critically examine what has been considered by the employers, the courts, the CCMA, and the bargaining council as dismissible social media misconduct. It is a critical analysis of what is currently considered to be social misconduct in the workplace. This will be done by comparing a dismissal and the constitutional rights such as the right to privacy and freedom of expression as having been raised by the employees during the hearing on a social misconduct charge. After such examination, the article examines what impact this has on employees and

For e.g., the employer may use social media to strategise the business - which may include the facilitation of the employer's recruitment; development and management skills; and publicising its market.

2 These guidelines are given on a case-by-case basis, which makes it difficult to conclude that they govern the employee's social behaviour in its entirety. 
also their participation in social media. This is particularly important where an employee has posted comments which have nothing to do with the employer - but yet they are dismissed. Recommendations will then be made on what can be done to restrict these dismissals, especially when the employee argues that he/she was not aware that the comments made could amount to dismissible misconduct.

\section{BACKGROUND: THE LAW AND THE USE OF SOCIAL MEDIA}

\section{Right to freedom of expression and right to privacy}

The right to freedom of expression and the right to privacy are often raised as a defence for those facing social media misconduct charges. The employees tend to argue that when they were making comments on social media, they were exercising their right to freedom of expression. On the face of it, this may well be true, because s 16(1) of the Constitution ${ }^{3}$ provides that "everyone has the right to freedom of expression, which includes freedom of the press and other media; freedom to receive or impart information or ideas; freedom of artistic creativity; and academic freedom and freedom of scientific research". The term "and other media" may well be said to include social media. Therefore, this means that the employees do have a right to make commentary on social media. However, most employees fail to read further to s 16(2), which continues to state that "the right in subsection (1) does not extend to propaganda for war; incitement of imminent violence; or advocacy of hatred that is based on race, ethnicity, gender or religion, and that constitutes incitement to cause harm". Section 16 is a general law that applies to everyone who lives in South Africa. The question is - what does this mean to both the employer and the employee? Does it mean that the employer can simply apply this general law to the workplace for the purposes of social media misconduct by an employee or must the employer still comply with labour law legislation which may have its own guidelines regulating the procedure for fair dismissal?

Other than the right to freedom of expression, s 14 of the Constitution provides that "everyone has the right to privacy, which includes the right not to have their person or home searched; their property searched; their possessions seized; or the privacy of their communications infringed". In the context of social media, $s 14(d)$ is the most relevant, as it provides that everyone has a right not to have their communication infringed. In other words, it may be said that employees enjoy the right not to have their social media communication infringed.

Although there are these rights, several employees have been dismissed either by limiting the right to privacy or limiting the right to freedom of expression. It is clear that social media and the misconduct following from the use of social media, affect human rights. Without the specific legislation

3 The Constitution of the Republic of South Africa, 1996. 
that regulates the use of social media by employees, however, there is possible harm to both the employer and employee. On the one hand, it becomes difficult for the employer to impose sanctions on the employee for misconduct, while on the other hand applying the law broadly may have a negative impact on the employee's rights.

\section{Fair or unfair dismissal}

The Labour Relations $\mathrm{Act}^{4}$ (LRA) is one of the statutes that governs the relationship between the employer and employee. As a statute that governs this relationship, it also gives guidelines on what constitutes a fair dismissal. Section 188(1) provides that a dismissal "is unfair if the employer fails to prove that the reason for dismissal is a fair reason related to the employee's conduct or capacity; or is based on the employer's operational requirements; and that the dismissal was effected in accordance with a fair procedure". Within the LRA there is also Schedule 8 of the Code of Good Practice, which gives further guidelines on what amounts to a fair dismissal. Schedule 8 item 7 provides that "any person who is determining whether a dismissal for misconduct is unfair should consider whether or not the employee contravened a rule or standard regulating conduct in, or of relevance to, the workplace; and if a rule or standard was contravened, whether or not the rule was a valid or reasonable rule or standard; the employee was aware, or could reasonably be expected to have been aware, of the rule or standard; the rule or standard has been consistently applied by the employer; and dismissal was an appropriate sanction for the contravention of the rule or standard".

The use of social media has created challenges for the courts, CCMA, and bargaining council, when interpreting Schedule 8 item 7 provisions and the social media misconduct by an employee. This has been even more difficult where the employer does not have any rules and guidelines regulating the employee's conduct on social media. It is therefore imperative to deal with these cases and examine how the courts have interpreted a fair dismissal, even if Schedule 8 item 7 is not met by the employer.

\section{SOCIAL MEDIA MISCONDUCT AND DISMISSAL}

\section{Dismissal for misconduct and the right to privacy}

In the context of social media and workplace, s 14(d) of the Constitution protects the employee from having their social media account hacked. However, one may ask the questions - does an employee have a right to privacy if such employee has made derogatory comments on social media that the employer has access to? What if the employer is not aware of those comments, but is informed by the public and then later opens the employee's social media account to confirm if there are indeed derogatory

$4 \quad 66$ of 1995. 
comments? Does it mean that the right of the employee's privacy is affected? South African case law has engaged with these issues, and an illustration is given below on how this has been dealt with by the courts.

\section{Sedick $v$ Krisray (Pty) $L t d^{5}$}

The employer dismissed the applicants (De Reuck and Sedick) on the grounds of bringing the employer's name into disrepute on the public domain. The applicants challenged the decision of the employer as being both procedurally and substantively unfair dismissal. ${ }^{6}$ The dismissal was as a result of derogatory messages posted by the applicants about the respondent's owner and his family members. The comments include, but are not limited to:

- "But one cannot be happy in a family business, especially when the kids join the company after you have been there for six years and they try everything in their power to make you look stupid.

- Trust me no-one can put up with so much shit when the [f...ing] kids join the company! Now we have the son working there as well who has no idea but is pretending he has a clue!

- Office drama! Family business! Kids join the company with no experience! Need I say more ..."

The respondent argued that the dismissal was fair as the comments made by the applicants caused disrepute within the employer's business and had the potential to ruin the good name of the business. Represented by Ms Coetzee, the respondent argued that the seriousness of the comments made by the applicants had to be considered in the context of their position in the company ${ }^{8}$ and the comments being made in a forum which was fully accessible to anyone - including former and current employees, customers and suppliers. ${ }^{9}$ On the other hand, the applicants argued that they had not brought the name of the employer into disrepute as they had not made any direct references to the employer or the people. ${ }^{10}$ De Reuck further argued that her right to privacy had been infringed. ${ }^{1}$

The Commissioner rejected both of the applicants' arguments. Dealing with the issue of privacy, the court held that the internet and Facebook is a public domain unless access to such Facebook is restricted by its members. ${ }^{12}$ It appeared the applicants had failed to restrict access to their Facebook pages and the commentary was wholly in the public domain. Consequently, the court found that the respondent, through Ms Coetzee,

[2011] 8 BALR 879 (CCMA).

Par 8.

Par 31.

De Reuck was a representative of the company on a day-to-day basis to both customers and suppliers, while Sedick was the bookkeeper and dealt with the private investments of the respondent's owner.

$9 \quad$ Par 34 and 37.

10 Par 39.

11 Par 42.

12 Par 50. 
was entitled to intercept the comments that had been made by the applicants. ${ }^{13}$ The Commissioner held that by failing to restrict access to their Facebook accounts, the applicants abandoned their right. On the issue of bringing the name of the employer into disrepute, the Commissioner found that indeed the applicants had brought the name of the employer into disrepute in the public domain. ${ }^{14}$ In reaching the decision, the Commissioner took into account "what was written; where the comments were posted; to whom they were directed, to whom they were available and last but by no means least, by whom they were said". ${ }^{15}$ Consequently, it was found that the comments had the potential to damage the reputation of the employer among its customers, suppliers, and competitors.

\section{Fredericks $v$ Jo Barkett Fashions ${ }^{17}$}

The applicant was dismissed on the grounds of destroying the name of the employer in public. The facts were, briefly, that the applicant had used her Facebook account to publish derogatory remarks about the employer's General Manager. The remarks had the potential to affect 90 employees and key customers which generated revenue for the employer. ${ }^{18}$ The applicant was therefore charged and dismissed. She challenged the dismissal as being unfair as it affected her right to privacy, as this was infringed. ${ }^{19}$

The Commissioner found that the dismissal was fair. ${ }^{20}$ In reaching the decision, the court determined the fairness of the dismissal by interpreting Schedule 8 Item 7 of the Code of Good Practice. ${ }^{21}$ Although it was clear from the facts that the employer had no policy concerning Facebook usage, the Commissioner found that the applicant's actions were not justifiable, and therefore the dismissal was fair. ${ }^{22}$ Comparing the facts before it with Sedick $v$ Krisray (Pty) Ltd, the Commissioner took the view that the applicant had also failed to restrict access to her Facebook profile, as it was open to public and anybody could access it. ${ }^{23}$

In both of these cases, the employees were dismissed for posting derogatory remarks on their social media. The basis of their arguments was that their right to privacy was infringed. In both cases the Commissioner found their arguments to be unfounded. Their failure to restrict access to their social media waived their right to privacy - as the posts were visible to everyone. From the cases above, it is clear that if the employee makes derogatory comments on social media, such comments do affect and in fact,

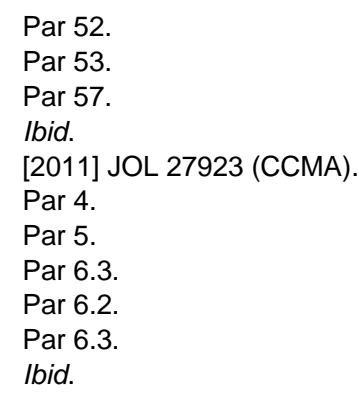


limit the employee's right to privacy. As long as the remarks can be accessed by the public, then the employer's conduct in terms of accessing those comments without the employee's consent is justified. From the cases above, it is clear that what needs to be proved is that there were derogatory comments made in public - without any restriction in terms of accessing those comments.

What is not clear, however, is what the situation would be if there were restricted access to the employee's social media account. Can the employee successfully raise the defence of the right to privacy under such circumstances? In Smith $v$ Partners in Sexual Health (Non-Profit), ${ }^{24}$ the employee successfully raised her right to privacy, after the employer accessed her private email account. The facts were, briefly, that while on leave, the applicant had her private Gmail account accessed by the employer's CEO. The emails made reference to internal matters, and were given to former employees and persons outside the organisation. Based on these emails, the applicant was charged and dismissed. The applicant then made an application to the Commissioner arguing that her dismissal was procedurally and substantively unfair. ${ }^{25}$ The Commissioner concluded that the applicant's dismissal was indeed procedurally and substantively unfair. ${ }^{26}$ The Commissioner found that the employer's conduct had breached the provisions of the Regulation of Interception of Communications and Provision of Communication-Related Information Act 70 of $2002 .{ }^{27}$ It was concluded by the Commissioner the comments made on social networks should be distinguished from the private emails intended for the recipient's eyes only.

Although this case made a distinction between private email and social media comments, it did not give clarity on the issue where the social media account is restricted from the general public. Strictly applying the principle of this case, one may conclude that posting on a restricted social media page is similar to sending an email to the recipient. If the employee's social media is restricted, this means that what the employee posts are for the eyes of his/her specific "friends" only. What becomes the problem though, is what if the employer becomes aware of the comments made on a restricted social media page - does it mean that the employee's right to privacy is affected? In the above two cases, ${ }^{29}$ the Commissioner found the dismissal to be fair because the employees had failed to restrict access to their Facebook accounts. Both cases did not however touch on the issue of the restricted access on the employee's Facebook account. It is therefore not clear whether the employee's right to privacy is affected if access to the social media account is restricted to specific people. As it stands, the employer's access to the employee's social media accounts will be justified if the employee did not restrict access to the comments made on their social

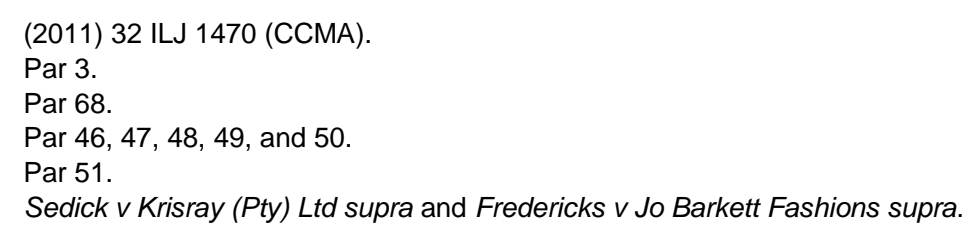


media. This would be the case, even if the employer had accessed the employee's social media - only to confirm what had been said by the public. $^{30}$

\section{Dismissal for misconduct and the right to freedom of expression}

The right to freedom of expression and the issue of bringing the name of the employer into disrepute is a serious legal issue that has an impact on the relationship between the employer and employee. What has become clear is that employees do make comments about their employers on social media. This may be a case where the employee makes comments in general for internet users to see, or it may be a conversation between the employees. However, some of those comments - when viewed by the employer - have the potential to damage the reputation of the employer. Cases have created what can be viewed as guidance if there is a clash between the employee's right to privacy and the social media comments that may damage the reputation of the employer or bring the name of the employer into disrepute.

\section{Media Workers Association of SA obo Mvemve $v$ Kathorus Community Radio ${ }^{31}$}

The applicant was dismissed for failure to post an apology on social media after he had posted malicious remarks on Facebook criticising the employer's board for protecting its station manager and for claiming that the manager was a criminal. These remarks were brought to the attention of the employer, and the applicant was charged and later dismissed. The applicant made an application to the CCMA, alleging that the dismissal was substantively unfair. ${ }^{32}$ However, the Commissioner dismissed the applicant's allegations and held that the applicant "tarnished the image of the respondent by posting unfounded allegations on Facebook without first addressing them internally". ${ }^{33}$ Accordingly, the dismissal of the applicant was held to be substantively fair. ${ }^{34}$

\section{Chemical Energy Paper Printing Wood \& Allied Union obo Dietlof $v$ Frans Loots Building Material Trust t/a Penny Pinchers ${ }^{35}$}

This case dealt with the issue of racism between the employer and employee. The applicant who was an employee of the respondent had posted comments on his Facebook page alleging racism by his employer.

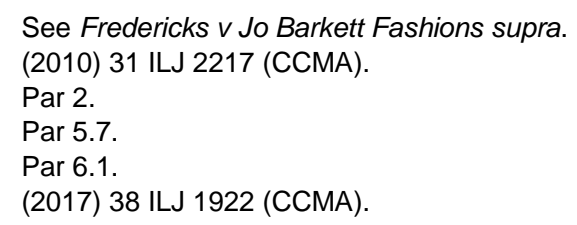


The applicant posted remarks on Facebook alleging that the owner, the respondent, had acted in a racist manner toward two long-service employees when he (the owner) deliberately kissed the white female employee on the cheek and hugged the black female employee. ${ }^{36}$ When giving evidence, the applicant argued that the post did not mention or have any relevance to the employer. ${ }^{37}$ However, on the evidence given by the respondent - through its owner - the remarks referred to the respondent. According to the respondent, although there was no reference to its name, the wording and construction of the comments indicated an incident could be directly linked to the respondent. ${ }^{38}$ The pictures posted on Facebook appeared to have been taken at the respondent's premises, and events mentioned in that post were the same set of events that had occurred at the respondent's event. ${ }^{39}$

Although the respondent did not have rules or policies on social media, the Commissioner found that the applicant's dismissal was procedurally and substantively fair. ${ }^{40}$ The Commissioner - citing J Grogan ${ }^{41}$ - held:

"to falsely accuse a superior or colleague of being a racist is as deplorable as racism itself. The dismissal of an employee who had done so was ruled to be

In both of the above cases, it is clear that the employee's right to freedom of expression can be limited, if it has the potential to defame or damage the reputation of the employer. If the employee makes remarks on social media, and they are later proved to have the potential of damaging the reputation of the employer, dismissal by the employer may be said to be justified. Whether or not the name of the employer is referenced, as long as the employer can prove that the comments made on social media have a direct link to its name - the employer may dismiss the employee. ${ }^{43}$ As long as the comments can bring the name of the employer into disrepute, it appears that the employer may fairly dismiss the employee for those comments.

However, there is a further issue on the employee's freedom of expression and the comments made on social media. In the all of the above cases $^{45}$ either the reference was made directly to the name of the employer,

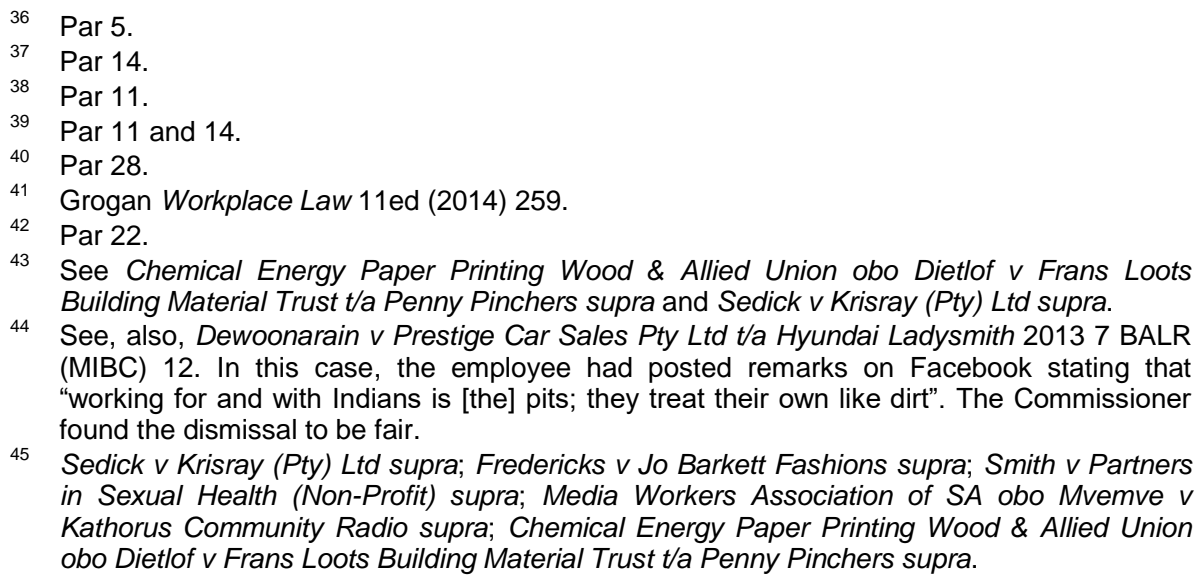

45 Sedick v Krisray (Pty) Ltd supra; Fredericks v Jo Barkett Fashions supra; Smith v Partners in Sexual Health (Non-Profit) supra; Media Workers Association of SA obo Mvemve v Kathorus Community Radio supra; Chemical Energy Paper Printing Wood \& Allied Union obo Dietlof v Frans Loots Building Material Trust t/a Penny Pinchers supra. 
or, if not, the employer could prove that there was a link between its name and the derogatory comments made on social media by an employee. These cases did not touch on whether an employee can be dismissed for the derogatory comments made on social media - even if those comments are made in a personal capacity, and they are not related to the employer.

Dismissal of employees in such circumstances is increasing in South Africa. It appears that even if the employee does not name the employer or if there is a link to the name of the employer, the employee may still be dismissed for posting controversial remarks on social media. The media coverage and court cases have shown that posting controversial remarks on social media can lead to the employee being dismissed. In most cases, these controversial statements are based on race and gender differences. This is a problem, because many of these remarks are being made in personal capacities. Below are some examples of dismissible derogatory comments made by employees on social:

Penny Sparrow is a white woman who made derogatory comments about black people - by calling them monkeys. On her Twitter account she posted:

"These monkeys that are allowed to be released on New Year's eve and New Year's day onto public beaches, towns etc obviously have no education what so ever so to allow them loose is inviting huge dirt and troubles and discomfort to others."

These remarks led to a national outcry calling for Ms Sparrow to be charged for racism. After the incident, Ms Sparrow's employer distanced itself from her views by stating:

"Comments made by an ex-employee is threatening a company that is built on integrity, morals and values. We are consulting an attorney to deal with this matter and the damage this woman has done to our company ... Penny Sparrow's comments are appalling and degrading and this is not someone we align ourselves with."

Justine Sacco was also dismissed after tweeting racist comments. Justine tweeted:

"Going to Africa. Hope I don't get AIDS. Just kidding. I'm white!"48

The employer distanced itself from her and her comments. In its statement, the employer said:

"The offensive comment does not reflect the views and values of IAC. We take this issue very seriously, and we have parted ways with the employee in question.

46 Wick "Twitter Erupts after KZN Estate Agent Calls Black People 'Monkeys"' (04 January 2016) Mail \& Guardian https://mg.co.za/article/2016-01-04-twitter-erupts-after-kzn-estateagent-calls-black-people-monkeys (accessed 2019-05-28).

47 Omar "PennySparrowMustFall: Estate Agent Feels Twitter Wrath after Racist Post" (04 January 2016) eNCA https://www.enca.com/south-africa/penny-sparrow-feels-twitter-wrath (accessed 2019-05-28).

48 Ronson "How One Stupid Tweet Blew Up Justine Sacco's Life" (12 February 2015) The New York Times Magazine https://www.nytimes.com/2015/02/15/magazine/how-one-stupidtweet-ruined-justine-saccos-life.html (accessed 2019-05-28). 
Furthermore, the Hot 91.9 FM Radio station also dismissed its own DJ, after he called Mr Julius Malema "a monkey" live on air. It did not matter that the DJ had apologised; he was still dismissed. In its statement, the employer said:

"As such, notwithstanding the presenter's immediate and unreserved apology, the station has forthwith elected to remove him from all involvement with the radio station with immediate effect."

Jessica Leandra - although not dismissed - lost her sponsors after tweeting derogatory comments about black people. In her response, she retweeted:

"I tweeted rather irresponsibly about an incident I encountered last night, using a harsh and unkind word about the gentleman who had confronted me with sexual remarks and sounds," she wrote in her apology ... "While most of you would enjoy the opportunity to throw a few vicious words at me, please do understand that I was acting in pure anger and frustration at the time and although we know this is no excuse, it is a lesson learnt and again, I am sincerely apologetic."

In all these examples, the employees posted comments in their personal capacities. However, because they were viewed as controversial and derogatory comments, these employees were dismissed. The employers only had to concern themselves with their reputation, and they then dismissed the employees concerned.

Not only did the employers dismiss employees for controversial comments, the courts have confirmed that controversial remarks on social media can amount to a dismissible offence. The recent judgments have shown that the courts tend to agree with dismissal if the employee has made controversial comments on social media.

\section{Gordon v National Oilwell Varco ${ }^{52}$}

The applicant was charged and dismissed for making racist remarks on social media. After his mother was injured after an ambulance hijacking, the applicant posted Facebook remarks and said:

"my mom [is] back in hospital again since last night after her ambulance got hijacked by pieces of $s^{*} t k^{* * * *} s$ wanting a ride with the ambulance for their $f^{\star \star \star * \star} g$ knife stabbing. I am getting fed up with his country. Will it ever come right again, I doubt it maybe just move out of the country."

49 Broderick 'Internet Erupts after PR Woman for Media Firm Tweets a 'Joke' About Getting AIDS in Africa" (20 December 2013) BuzzFeedNews https://www.buzzfeednews.com/ article/ryanhatesthis/internet-uproar-erupts-after-pr-woman-for-media-firm-tweets (accessed 2019-05-28).

50 Sun Reporter "DJ Fired For Calling Juju a 'Monkey'!" (02 October 2018) Daily Sun https://www.dailysun.co.za/News/National/dj-fired-for-calling-juju-a-monkey-20181002 (accessed 2019-05-28).

51 Marshall "Controversial SA tweets of 2012" (12 December 2012) Mail \& Guardian https://mg.co.za/article/2012-12-12-controversial-tweets-of-2012 (accessed 2019-05-28).

52 [2017] 9 BALR 935 (MEIBC).

53 Par 9. 
The evidence given by the employer was that the applicant knew about social media guidelines as he had signed them when started as an employee ${ }^{54}$ In his defence, he argued that the remarks were posted out of despair. ${ }^{55}$ However, the Commissioner held that racial slurs are not acceptable in the workplace, and therefore the dismissal of the applicant was fair. $^{56}$

\section{Dyonashe $v$ Siyaya Skills Institute (Pty) Ltd $^{57}$}

The Commissioner had to assess whether the applicant's dismissal was fair. The applicant had been dismissed for posting racist comments on Facebook and for bringing the name of the employer into disrepute. ${ }^{58}$ The applicant had posted remarks "Kill the Boer, we need to kill these". ${ }^{59}$ The respondent represented by Laura Mace - argued that "kill the boer" was a racist remark that was disturbing, and the applicant had posted this on his Facebook page, which was a public domain. ${ }^{60}$ The applicant, on the other hand, argued that "kill the boer" in his understanding did not mean kill the whites - but rather the system that is there to oppress one side. ${ }^{61} \mathrm{He}$ argued that he did not think that white people would take this as an offence as he had white friends, and people who were close to him did not have a problem. ${ }^{62}$

The Commissioner found that although the applicant neither mentioned the employer's name nor was at work when he posted these comments, there was a nexus between the applicant's conduct and his employment relationship with the respondent, which affected his suitability for employment. ${ }^{63}$ The Commissioner held that even if there was no policy, the CCMA Guidelines were sufficient to render the dismissal as being fair. ${ }^{64}$ According to the Commissioner the test to be used in the CCMA Guidelines was "whether the employer could fairly have imposed the sanction of dismissal in the circumstances, either because the misconduct on its own rendered the continued employment relationship intolerable, or because of the cumulative effect of the misconduct when taken together with other instances of misconduct". ${ }^{65}$

The dismissal of employees for social media misconduct and controversial remarks is not limited to the above case, as the employee in Ward $v$ South African Revenue Services ${ }^{66}$ was also dismissed for calling a co-employee a

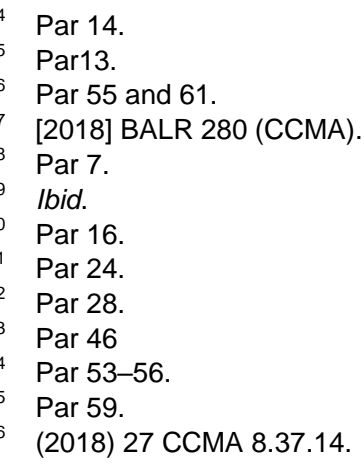


monkey. The labour court has also confirmed that posting controversial and racist comments on social media is a dismissible offence, as Facebook can be taken to be a quasi-public forum accessible to potentially thousands of Facebook users.

\section{ANALYSIS OF THE CURRENT SITUATION}

Without a doubt, the employer is always very particular about their reputation. The employer's reputation is and has always been an asset that needs protection, and, if such is negatively impacted - this can cause harm to the employer's business. ${ }^{68}$ The question that remains is whether the employers, courts, and commissioners have broadened the scope of dismissing employees for social media misconduct. Although some employers have social media guidelines in their workplace, even in the absence of such guidelines, employees have found themselves dismissed for social media misconduct. Several cases that come before the courts, the CCMA, or bargaining council have taken an approach that it is a dismissible offence for the employee to knowingly post comments on social media - if such remarks negatively affect the employer.

It is clear from the above discussion that despite the employee's subjective belief that the remarks are made in their personal capacity, the objective approach is used to test those remarks. The employee cannot merely escape dismissal on the grounds that the remarks were subjectively seen by that employee as a joke. It also does not matter that the employee had left the workplace and/or was acting in his/her private capacity outside working hours when making the remarks. The employer is entitled to terminate an employee's employment, even if the employee's conduct was outside the workplace - as long as the employer can show the employee's conduct has affected its interests. Even if the employer is without the policies or rules regulating the use of social media by employees, the employee may be dismissed for what may be viewed by the employer as derogatory remarks. It appears that there are certain standards of ethics that are expected of employees, without a need to have such being encompassed in the employer's employment policies. The unavailability of such standards

Furthermore, both the right to freedom of expression and the right to privacy are limited by the employer's reputation. If the comments made on social media have the potential to bring the name of the employer into disrepute, the employee may be dismissed for social media misconduct. Because of this, two arguments are advanced. From a business perspective, protecting the employer's name and business is more important than the comments made by the employee - if such comments can harm the employer's business. Without a doubt, the employees play an important role in the success of the employer's business. Therefore, if they make negative remarks on social media, their remarks may seriously damage the employer's business.

67 Dagane $v$ South African Police (2219/14) [2018] ZALCJHB (16 March 2018).

68 Mushwana and Bezuidenhout "Social Media Policy in South Africa" 201416 Southern African Journal of Accountability and Auditing Research 64. 
However, from a human rights perspective, protecting the employer's name even if the employer has no social media rules and guidelines in its workplace - seem to broaden the scope of dismissing employees, especially if the comments are not directed at the employer. Even more, the LRA and Schedule 8 of the Code of Good Practice have provided guidelines on how the employee may be dismissed. In the above examples and cases where the employees were dismissed, it is not apparent how the employer and Commissioner have applied the LRA and Schedule 8 in deciding that the dismissal is fair. What is said by the employer and Commissioner is that the remarks made by the employee have the potential to damage the employer's good name. Therefore, one may conclude that the employer and the Commissioner have indeed broadened the scope of protecting employers. From a human rights perspective, this appears to mean that the good name of the employer is more important than the employee's rights. Surely this has a bearing in a democratic society such as South Africa. If challenged, this could lead to a floodgate of cases which may have a negative effect on South African labour law.

\section{RECOMMENDATIONS}

This article has shown that social media misconduct and the right to freedom of expression and privacy are clashing in South Africa. Without the proper legislation regulating the use of social media by employees, there will still be problems in South African labour law. It is therefore recommended that legislation regulating social media in South Africa should be implemented. Reddy argues that with legislation regulating social media in South Africa, social media conduct may be improved. ${ }^{69}$ In the meantime - while no legislation is in place - employers must have their own in-house guidelines on the use of social media by employees. Once this has been done, the employee should be made aware of such guidelines. Adopting these guidelines may render the dismissal to be unquestionably substantively and procedurally fair. This may be advantageous to both the employer and the employee - because costly litigations can then be avoided.

Similarly, it is recommended that employees should also exercise caution when expressing their views on social media. Without the legislation in place, they are likely to find themselves dismissed, simply for putting the name of the employer into disrepute. Even more so, without the definition and meaning of "putting the name of the employer into disrepute" employees may be dismissed under the circumstances viewed by the employer as putting its name into disrepute. Employees should be aware that with or without the social media policy in place, it is a dismissible offence to post remarks that may be viewed as bringing the name of the employer into disrepute. It does not matter whether those remarks were made in a personal capacity - they are still considered as social media misconduct. If there is a social media policy put in place by the employer, the employees should become well acquainted with that policy, bearing in mind that failure

69 Reddy "Establishing a Test for Social Media Misconduct in the Workplace" 20184 TSAR 817. 
to comply with the policy may result in a dismissal. Their remarks on social media must be kept to a minimum, bearing in mind the ethics and code of conduct of the employer. It is true that social media is a platform where some people share their opinions. However, an employee must limit what they say on social media - as such thoughts may result in charges of social media misconduct.

\section{CONCLUSION}

Social media has created a blurred line in terms of what constitutes the "work" and "private life" of an employee when the employee makes remarks on social media. This will likely cause employees to be very sceptical of what to post and what not to post on social media. The question that remains then is whether this makes life difficult for employees. As it stands, every employee who has access to social media runs the potential risk of being dismissed for comments made on social media. The courts, the CCMA, and bargaining councils have found dismissals to be fair where it is proved that the social media misconduct affects the employer. It appears, although it is not explicitly stated, that the courts consider the common law contract of employment duties when dealing with the issue of social media misconduct. These duties include that the employee has a duty to act honestly, in the best interests of the employer, and should not bring the employer's name into disrepute. These duties are wide enough to include any conduct that may be viewed by the employer as social media misconduct. Without the specific required legislation, it appears that if the employee breaches ${ }^{70}$ these duties, such an employee may be dismissed for social media misconduct. Therefore, it may be said that without the specific legislation, employees should refrain from posting comments that are likely to be viewed as being misconduct. This is irrespective of whether their privacy settings on social media are activated.

70 An employer may view social media remarks as misconduct, while an employee does not see such remarks as a breach of duties - which then results in a difficult position for both the employer and employee. 